\title{
A New Model for Multiply Charged Adduct Formation Between Peptides and Anions in Electrospray Mass Spectrometry
}

\author{
Xiaohua Liu, Richard B. Cole
}

Department of Chemistry, University of New Orleans, 2000 Lakeshore Dr., New Orleans, LA 70148, USA

\begin{abstract}
A new model has been developed to account for adduct formation on multiply charged peptides observed in negative ion electrospray mass spectrometry. To obtain a stable adduct, the model necessitates an approximate matching of apparent gas-phase basicity ( $\mathrm{GB}_{\mathrm{app}}$ ) of a given proton bearing site on the peptide with the gas-phase basicity (GB) of the anion attaching at that site. Evidence supporting the model is derived from the fact that for [Glu] Fibrinopeptide B, higher GB anions dominated in adducts observed at higher negative charge states, whereas lower GB anions appeared predominately in lower charge state adducts. Singly charged adducts were

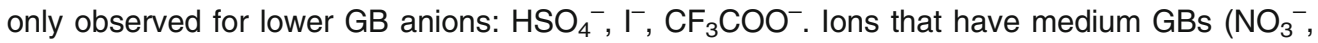
$\mathrm{Br}^{-}, \mathrm{H}_{2} \mathrm{PO}_{4}^{-}$) only form adducts having -2 charge states, whereas $\mathrm{Cl}^{-}$(higher $\mathrm{GB}$ ) can form adducts having -3 charge states. The model portends that (1) carboxylate groups are much more basic than available amino groups; (2) apparent GBs of the various carboxylate groups on peptides do not vary substantially from one another; and (3) apparent GBs of the individual carboxylate and amino sites do not behave independently. This model was developed for negative ion attachment but an analogous mechanism is also proposed for the positive ion mode wherein (1) binding of a neutral at an amino site polarizes this amino group, but hardly affects apparent GBs of other sites; (2) proton addition (charge state augmentation) at one site can decrease the instrinsic GBs of other potential protonation sites and lower their apparent GBs.
\end{abstract}

Key words: Anion attachment, New model, Multiple charging, Adduction, Electrospray, Negative ion, Adduct formation, Gas-phase basicity, Apparent gas-phase basicity, Adduct stability, Salt bridge, Proton bound dimer, Peptide, Protein, Basic sites, Reciprocal stabilization of opposite charges

\section{Introduction}

Tn analytical mass spectrometry studies of peptides and other biomolecules, the interpretation of mass spectra often becomes complicated when more than one small molecule species forms adducts with a given analyte. Moreover, the presence of such multiply adducted species disperses the analyte signal over several $\mathrm{m} / \mathrm{z}$ values, thus raising detection limits. Effects of anions on peptides/ proteins have been investigated in solution as far back as

Correspondence to: Richard B. Cole; e-mail: rcole@uno.edu the late 19th century, when Hofmeister evaluated the abilities of various anions to precipitate or "salt out" proteins, resulting in the so-called "Hofmeister series" for anions listed in part as: $\mathrm{SO}_{4}{ }^{2-}>\mathrm{Cl}^{-}>\mathrm{NO}_{3}{ }^{-}>\mathrm{Br}^{-}>\mathrm{I}^{-}>$ $\mathrm{ClO}_{4}{ }^{-}>\mathrm{SCN}^{-}$[1]. Since the introduction of the Hofmeister series, the relative ranking of the anions has been correlated to a wide range of chemical solution parameters [2].

Compared with the number of investigations into solution phase behavior, far fewer reports have investigated the effects of anions on the gas-phase properties of peptides/ proteins. Mirza and Chait [3] found that the presence of certain anionic species in initial solutions caused positive ion electrospray mass spectra to undergo shifts in peptide and 
protein charge states toward lower values compared with solutions devoid of these anions. A two step mechanism was proposed to account for this charge reduction effect: the first step is a solution phase pairing of an anion with a positively charged basic group on the peptide; the second step occurs during desolvation, or afterwards in the gas phase, where the anion departs with a proton to yield the neutral acid and the peptide with a lowered charge state. The level of charge reduction was found to depend only on the characteristics of the anionic species and was not dependent on the source of the anion (acid or salt form). The authors noted that the level of charge reduction exerted by the series of anions followed the same trend as the tendency for these same anions to induce folding of globular proteins, and to be retained on an anion exchange column [4].

Our laboratory has been engaged in fundamental studies of anion attachment for quite some time [5-14]. Previous studies have all examined singly charged anionic adducts. One of the major findings was that the gas-phase basicity (GB, Table 1 [15-18]) of the attaching anion moiety vs. that of the deprotonated analyte molecule $\left([\mathrm{M}-\mathrm{H}]^{-}\right)$plays an important role in determining the stability of anionic adducts. That is, if we consider that anionic adducts take the form of a proton-bound mixed dimer of anions: [M $\mathrm{H}]^{-} \cdots \mathrm{H}^{+} \ldots$ [anion $]^{-}$, then such adducts will have maximum stability when the two anions have approximately equivalent GBs [8]. The present work extends our efforts into the domain of multiply charged, multiply adducted anions. It provides a systematic study of hydrophilic peptide-adduct complexes that aims to (1) elucidate the mechanism of multiple adduct formation in negative ion ES-MS (leading to multiply charged adducts); (2) characterize the sites on the protein to which anions attach; and (3) rationalize the pathways of gas-phase reactions that occur when proteinadduct complexes are subjected to sustained off-resonance irradiation collision induced decomposition (SORI-CID).

\section{Experimental}

All chemicals were purchased from Sigma-Aldrich (St. Louis, MO) and were used without further purification. Adduct formation between selected anions introduced as ammonium salts $\left(\mathrm{NH}_{4} \mathrm{X}\right.$ where $\mathrm{X}=\mathrm{HSO}_{4}^{-}, \mathrm{CF}_{3} \mathrm{COO}^{-}, \mathrm{H}_{2} \mathrm{PO}_{4}^{-}, \mathrm{Cl}^{-}, \mathrm{Br}^{-}$, $\mathrm{I}^{-}$, and $\mathrm{CH}_{3} \mathrm{COO}^{-}$), and model peptides ([Glu] Fibrinopeptide
B and ACTH 22-39) has been investigated, All experiments were performed in the negative ion mode on a Bruker (Billerica, MA, USA) Apex Qe 7.0 T Fourier transform ion cyclotron resonance (FT-ICR) mass spectrometer. To obtain a balance between obtaining reasonably strong signals and maintaining "soft" ionization conditions to promote adduct formation, voltages on the capillary exit and the skimmer were set to -35 and $-1.7 \mathrm{~V}$, respectively.

\section{Results and Discussions}

\section{Adduct Formation in Negative Ion Mass Spectra}

[Glu] Fibrinopeptide B is a hydrophilic peptide derived from Fibrinopeptide B amino acid residues 1-14. Its sequence is EGVNDNEEGFFSAR, and it consists of two basic sites (one at the arginine $(\mathrm{R})$ side chain and another at the $-\mathrm{NH}_{2}$ terminal end plus five acidic carboxylic acid sites $-\mathrm{COOH}$, three from side chains of glutamic acid (E), one from aspartic acid (D) and one from the $-\mathrm{COOH}$ end group).

Electrospray mass spectra of $3.2 \mu \mathrm{M}$ [Glu] Fibrinopeptide $\mathrm{B}$ in pure methanol solution, with 0 to $64 \mu \mathrm{M}$ ammonium salts are shown in Figure 1. Without addition of ammonium salts, the charge state distribution shows three charge states $-1,-2$, and -3 corresponding to removal of one, two, or three protons with no adducts from anion attachment observed at any of these three charge states (Figure 1a). Addition of $64 \mu \mathrm{M}$ ammonium bisulfate results in various extents of anion attachment to [Glu] Fibrinopeptide B (Figure 1b): $\mathrm{HSO}_{4}{ }^{-}$had the lowest $\mathrm{GB}(1265.0 \pm 10.0 \mathrm{~kJ} /$ mol) of all the anions investigated. $\mathrm{HSO}_{4}{ }^{-}$adduction occurs for lower charge state ions with the most intense adduct peaks appearing at the -2 charge state; however, [[Glu] Fibrinopeptide $\mathrm{B}-2 \mathrm{H}]^{2-}$ can hardly be seen. For the -1 charge state, [[Glu] Fibrinopeptide $\left.\mathrm{B}+\mathrm{HSO}_{4}\right]^{-}$adducts are observed. Moreover, up to two additional $\mathrm{H}_{2} \mathrm{SO}_{4}$ neutrals can attach to the peptide to form [[Glu] Fibrinopeptide $\mathrm{B}+$ $\left.\mathrm{HSO}_{4}+\mathrm{H}_{2} \mathrm{SO}_{4}\right]^{-}$and [[Glu] Fibrinopeptide $\mathrm{B}+\mathrm{HSO}_{4}+$ $\left.2 \mathrm{H}_{2} \mathrm{SO}_{4}\right]^{-}$. Compared with $\mathrm{HSO}_{4}^{-}$, when $\mathrm{I}^{-}$(GB $1293.7 \pm$ $0.84 \mathrm{~kJ} / \mathrm{mol}$ ) was added (Figure 1c) the singly charged adduct ion [[Glu] Fibrinopeptide $\mathrm{B}+\mathrm{I}]^{-}$decreased relative to [[Glu] Fibrinopeptide $\mathrm{B}-\mathrm{H}]^{-}$, and no additional $\mathrm{HI}$ neutral attached to the peptide at the -1 charge state. The charge states of anion adducted proteins increase with higher

Table 1. Gas-Phase Basicities of Tested Anions and Charge States of Adducts Formed with [Glu] Fibrinopeptide B

\begin{tabular}{lcc}
\hline \multicolumn{1}{c}{ Anion } & Anion gas-phase basicities $(\mathrm{GB})(\mathrm{kJ} / \mathrm{mol})$ & Adduct charge states observed for [Glu] Fibrinopeptide B \\
\hline $\mathrm{HSO}_{4}^{-}$ & $1265.0 \pm 10.0^{[15]}$ & $-1,-2$ \\
$\mathrm{I}^{-}$ & $1293.7 \pm 0.84^{[15]}$ & $-1,-2$ \\
$\mathrm{CF}_{3} \mathrm{COO}^{-}$ & $1328.0 \pm 8.4^{[15]}$ & $-1,-2$ \\
$\mathrm{NO}_{3}^{-}$ & $1329.7 \pm 0.84^{[15]}$ & -2 \\
$\mathrm{Br}^{-}$ & $1331.4 \pm 4.6^{[15]}$ & -2 \\
$\mathrm{H}_{2} \mathrm{PO}_{4}^{-}$ & $1351.0 \pm 21.0^{[15]}$ & -2 \\
$\mathrm{Cl}^{-}$ & $1373.6 \pm 8.4^{[16,17]}$ & $-2,-3$ \\
$\mathrm{CH}_{3} \mathrm{COO}^{-}$ & $1428.7 \pm 8.4^{[15]}$ & No detected signal \\
$\mathrm{F}^{-}$ & $1530.5 \pm 1.3^{[15,18]}$ & No detected signal \\
\hline
\end{tabular}




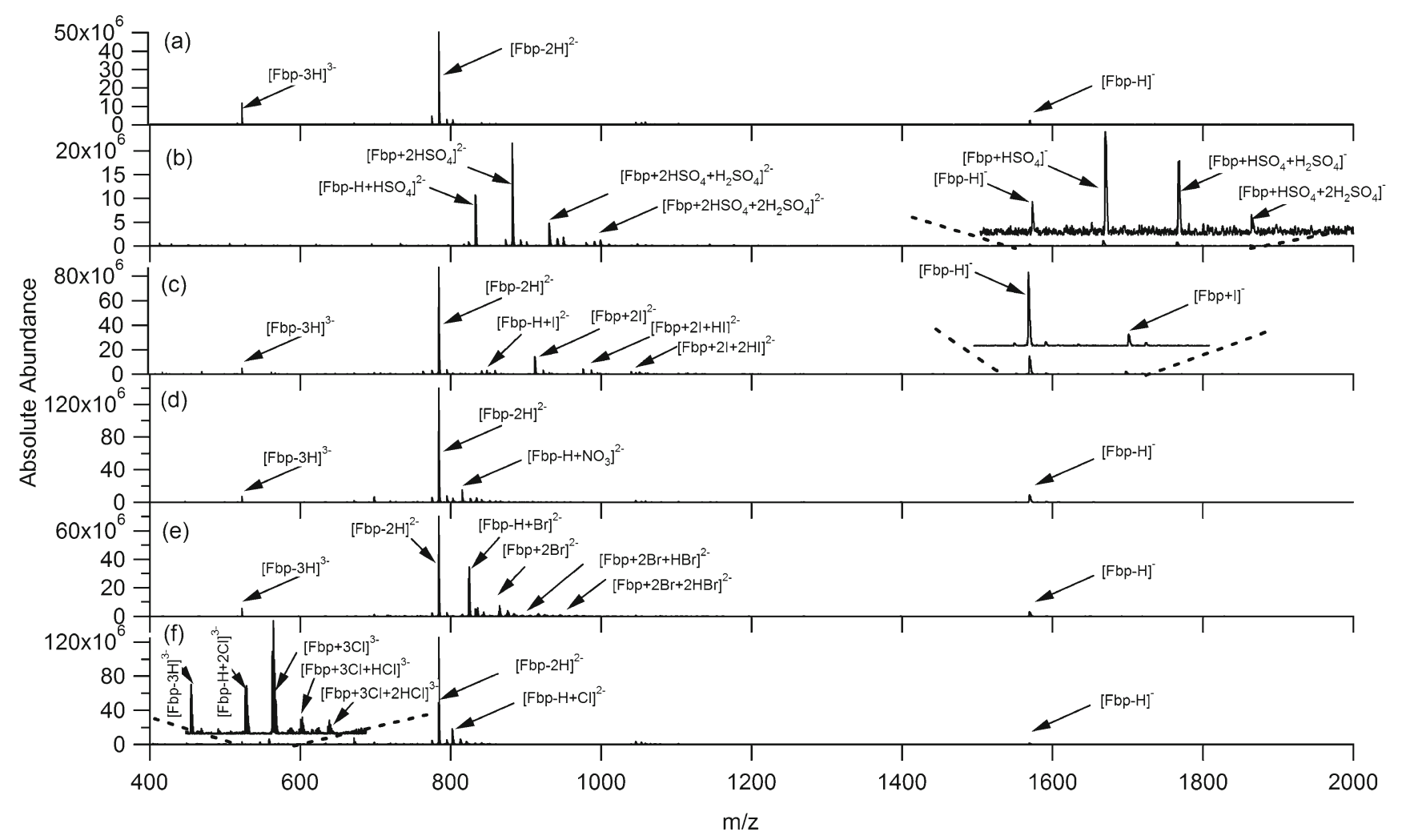

Figure 1. ES mass spectra of solutions containing 3.2 $\mu \mathrm{M}$ [Glu] Fibrinopeptide $\mathrm{B}$ (abbreviated Fbp) and (a) no additive; (b) $64 \mu \mathrm{M} \mathrm{NH}_{4} \mathrm{HSO}_{4}$; (c) $64 \mu \mathrm{M} \mathrm{NH}_{4}$ l; (d) $64 \mu \mathrm{M} \mathrm{NH}_{4} \mathrm{NO}_{3}$; (e) $64 \mu \mathrm{M} \mathrm{NH}_{4} \mathrm{Br}$; and (f) $64 \mu \mathrm{M} \mathrm{NH}_{4} \mathrm{Cl}$. Insets show blow-ups of adducts of $\mathrm{HSO}_{4}^{-}$and $\mathrm{I}^{-}$for -1 charge states, plus $\mathrm{Cl}^{-}$at -3 charge states

GB anions added. For example, $\mathrm{NO}_{3}{ }^{-}$and $\mathrm{Br}^{-}$with $\mathrm{GBs}$ of $1329.7 \pm 0.84 \mathrm{~kJ} / \mathrm{mol}$ and $1331.4 \pm 4.6 \mathrm{~kJ} / \mathrm{mol}$ respectively (Table 1), can only form adducts with [Glu] Fibrinopeptide $\mathrm{B}$ at -2 charge state (Figure 1d and e); for these two anions, no adducts with [Glu] Fibrinopeptide B were formed at -1 , -3 , or any charge state other than $-2 . \mathrm{Cl}^{-}$has a higher $\mathrm{GB}$ $(1373.6 \pm 8.4 \mathrm{~kJ} / \mathrm{mol})$ than all of the anions listed above. It also forms adducts having -2 charge state, however, in contrast to all of the others, $\mathrm{Cl}^{-}$can form adducts having -3 charge states, i.e., $[[\mathrm{Glu}] \text { Fibrinopeptide } \mathrm{B}+3 \mathrm{Cl}]^{3-}$ and [[Glu] Fibrinopeptide $\mathrm{B}-\mathrm{H}+2 \mathrm{Cl}]^{3-}$, but the $[[\mathrm{Glu}]$ Fibrinopeptide $\mathrm{B}-2 \mathrm{H}+\mathrm{Cl}]^{3-}$ peak was not observed (Figure 1f). Ions with even higher GBs than $\mathrm{Cl}^{-}$, e.g., $\mathrm{CH}_{3} \mathrm{COO}^{-}$, and $\mathrm{F}^{-}$, produced no observable adducts at any charge states. Thus, the predominant anion in appearing adducts was observed to change as the charge state of the peptide shifted. The higher GB anions dominated in adducts observed at higher negative charge states, whereas lower GB anions appeared predominately in lower charge state adducts.

Similar trends were observed for the peptide ACTH 22-39 with sequence VYPNGAEDESAEAFPLEF, which consists of one $-\mathrm{NH}_{2}$ terminal end group and six acidic carboxylic acid sites $-\mathrm{COOH}$, four from side chains of glutamic acid (E), one from aspartic acid (D), and one from the --COOH end group. Figure 2 shows electrospray mass spectra of $2 \mu \mathrm{M}$ ACTH $22-39$ in pure methanol solution, with 0 to $64 \mu \mathrm{M}$ ammonium salts. Without addition of ammonium salts, the charge state distribution displays three charge states $-2,-3$, and -4 (Figure 2a); peaks corresponding to sodium/proton exchange are visible at $\mathrm{m} / \mathrm{z}$ values just higher than the labeled peaks. Addition of $64 \mu \mathrm{M}$ ammonium bisulfate resulted in only -2 and -3 charge state ions, and bisulfate adducts only formed at the -2 charge state (Figure 2b). Similar results were obtained when $64 \mu \mathrm{M}$ ammonium bromide was added (Figure 2c). Although addition of ammonium chloride doesn't change the breadth of charge states observed, both -3 and -2 charge states were observed to be comprised of chloride adducts (Figure 2d).

\section{The Sites on Peptides Where Anions Attach}

In negative ion electrospray, there are two types of electrondeficient sites on peptides/proteins to which anions may attach: hydrogens of carboxylic acids and protonated amino (or imino) groups (positively charged). One obvious difference between these two types of attachment is that an anion attached to a carboxylic acid site adds a net negative charge to the peptide whereas anion attachment to a protonated basic site results in a neutralization of that site. For an ion appearing in the mass spectrum of the form: [peptide $+\mathrm{A}]^{-}$ (A represents an anion), two types of structures could be 


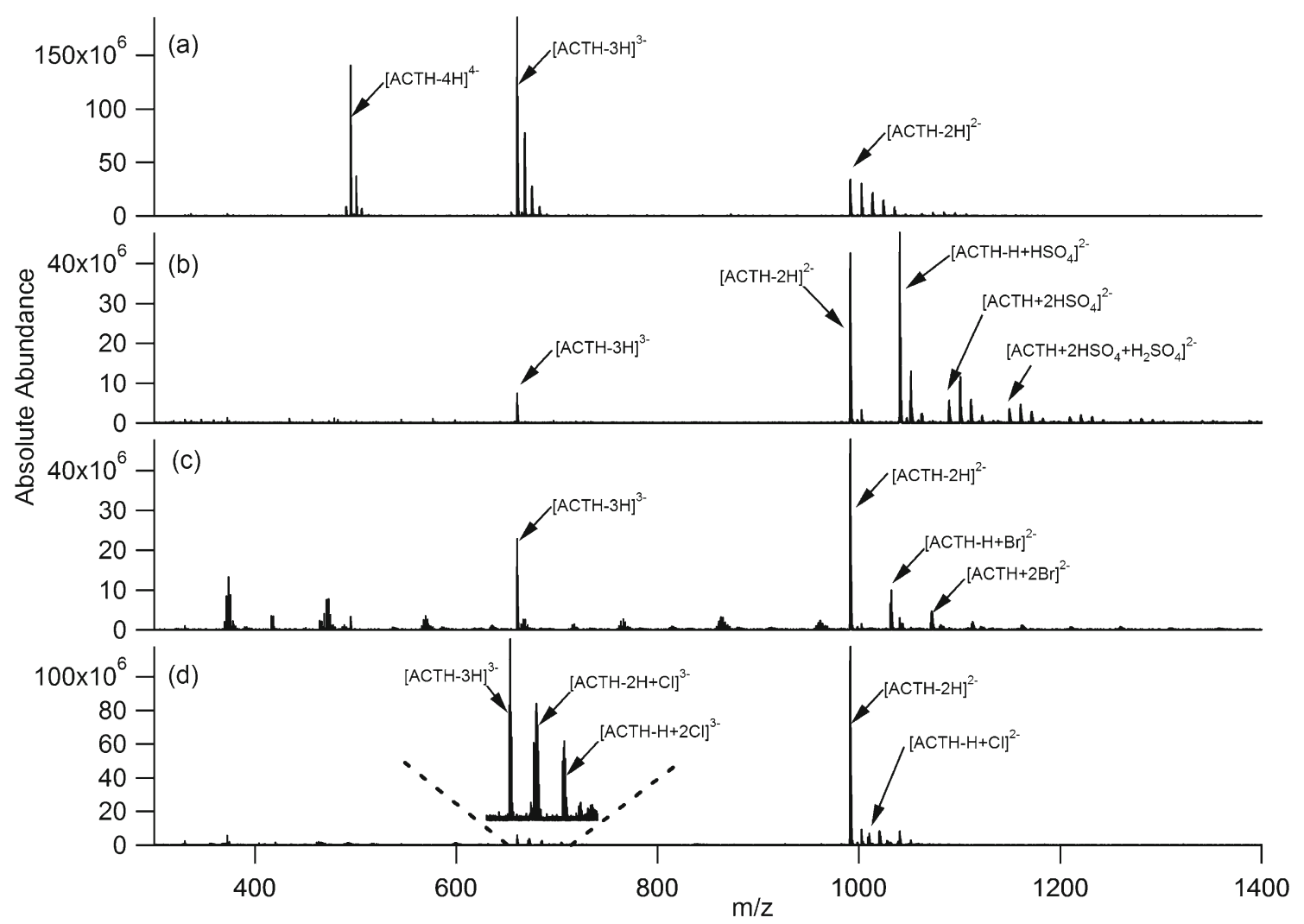

Figure 2. ES mass spectra of solutions containing $2 \mu \mathrm{M} \mathrm{ACTH} \mathrm{22-39} \mathrm{(abbreviated} \mathrm{ACTH)} \mathrm{and} \mathrm{(a)} \mathrm{no} \mathrm{additive;} \mathrm{(b)} 64 \mu \mathrm{M}$ $\mathrm{NH}_{4} \mathrm{HSO}_{4}$; (c) $64 \mu \mathrm{M} \mathrm{NH}{ }_{4} \mathrm{Br}$; and (d) $64 \mu \mathrm{M} \mathrm{NH}{ }_{4} \mathrm{Cl}$. Inset shows a blow-up of adducts of $\mathrm{Cl}^{-}$for the -3 charge state

envisioned (the dotted lines represent electrostatic attraction of varying strength):

$$
\begin{aligned}
& \mathrm{A}^{-} \cdots \cdot \mathrm{H}^{+} \cdots \cdots \mathrm{NH}_{2}-\text { Peptide }-\mathrm{COO}^{-} \\
& \mathrm{NH}_{2}-\text { Peptide }-\mathrm{COO}^{-} \cdots \cdot \mathrm{H}^{+} \cdots \cdots \mathrm{A}^{-}
\end{aligned}
$$

Prior to electrospray, however, this same peptide is likely to have existed in a neutral solution of moderate salt concentration as:

$$
\mathrm{A}^{-} \cdots \mathrm{H}^{+} \cdots \mathrm{NH}_{2}-\text { Peptide }-\mathrm{COO}^{-} \cdots \mathrm{H}^{+} \cdots \mathrm{A}^{-}
$$

During desolvation or shortly afterwards in the gas phase, sufficient internal energy is present to cause departure of $\mathrm{AH}$. The proton attached to the amino group will almost always require less energy to remove relative to the proton on the carboxylate group because the anionic carboxylate sites have far higher GBs than the neutral amino sites. Thus, Structure 1 would be much less favored to survive in the gas phase compared with Structure 2. Furthermore, this same logic implies that, upon desolvation, compounds bearing multiple adducted anions will undergo multiple HA losses from amino sites before any carboxylate sites holding HA lose that HA. An exception to this blanket statement can occur if salt bridge(s) form (see below). This reasoning is supported by experimental evidence given in the following section.

\section{Adduct Fragmentation: Anion Departure With or Without a Proton?}

A series of adduct ions were selected for MS/MS experiments via SORI-CID. MS/MS spectra of [[Glu] Fibrinopeptide $\left.\mathrm{B}-\mathrm{H}+\mathrm{HSO}_{4}\right]^{2-}$ and $[[\mathrm{Glu}]$ Fibrinopeptide $\mathrm{B}+$ $\left.2 \mathrm{HSO}_{4}\right]^{2-}$ are shown in Figure $3 \mathrm{a}$ and b, respectively. For [[Glu] Fibrinopeptide $\left.\mathrm{B}-\mathrm{H}+\mathrm{HSO}_{4}\right]^{2-}$, most of these ions dissociated to [[Glu] Fibrinopeptide $\mathrm{B}-\mathrm{H}]^{-}$and $\mathrm{HSO}_{4}^{-}$; far fewer lose $\mathrm{H}_{2} \mathrm{SO}_{4}$. [[Glu] Fibrinopeptide $\left.\mathrm{B}+2 \mathrm{HSO}_{4}\right]^{2-}$, which has two $\mathrm{HSO}_{4}^{-}$attachment sites, undergoes initial dissociation in two distinct steps: first losing $\mathrm{HSO}_{4}{ }^{-}$ followed by loss of $\mathrm{H}_{2} \mathrm{SO}_{4}$, giving rise initially to $\mathrm{HSO}_{4}{ }^{-}$ plus [[Glu] Fibrinopeptide $\left.\mathrm{B}+\mathrm{HSO}_{4}\right]^{-}$, and then $[[\mathrm{Glu}]$ Fibrinopeptide $\mathrm{B}-\mathrm{H}]^{-}$(Figure $3 b$ ). If, instead, $\mathrm{H}_{2} \mathrm{SO}_{4}$ loss had occurred first, a peak corresponding to [[Glu] Fibrinopeptide $\left.\mathrm{B}-\mathrm{H}+\mathrm{HSO}_{4}\right]^{2-}$ would be expected; no such peak was observed. The fact that the first loss is $\mathrm{HSO}_{4}{ }^{-}$can only be rationalized if one considers that this leaving $\mathrm{HSO}_{4}{ }^{-}$is weakly held to the peptide (Scheme 1, left column). It is highly unlikely that this $\mathrm{HSO}_{4}^{-}$was attached to a protonated 


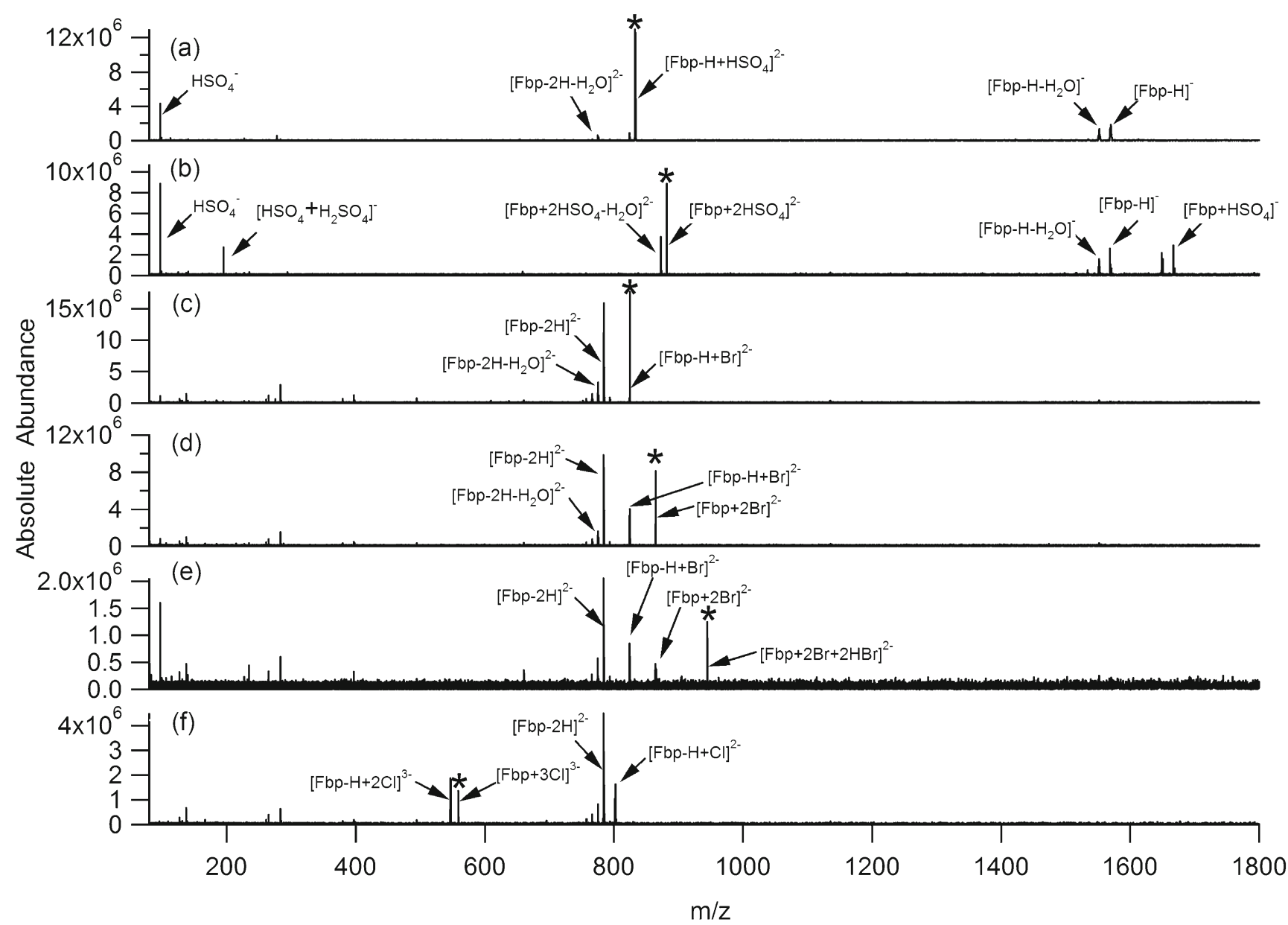

Figure 3. SORI-CID MS/MS spectra for the following precursors (a) $\left[[\mathrm{Glu}] \text { Fibrinopeptide } \mathrm{B}-\mathrm{H}+\mathrm{HSO}_{4}\right]^{2-}$; (b) $[[\mathrm{Glu}]$ Fibrinopeptide $\left.\mathrm{B}+2 \mathrm{HSO}_{4}\right]^{2-}$; (c) [[Glu] Fibrinopeptide $\left.\mathrm{B}-\mathrm{H}+\mathrm{Br}\right]^{2-}$; (d) [[Glu] Fibrinopeptide $\left.\mathrm{B}+2 \mathrm{Br}\right]^{2-}$; (e) [[Glu] Fibrinopeptide $\mathrm{B}+2 \mathrm{Br}+2 \mathrm{HBr}]^{2-}$; and (f) [[Glu] Fibrinopeptide $\left.\mathrm{B}+3 \mathrm{Cl}\right]^{3-}$. Asterisks ( $\left.^{*}\right)$ mark precursor ions; [Glu] Fibrinopeptide $\mathrm{B}$ is abbreviated as $\mathrm{Fbp}$

amino group because $\mathrm{H}_{2} \mathrm{SO}_{4}$ loss would have been expected from the amino site of low $\mathrm{GB}_{\text {app }}$ (see Appendix for discussion of $\mathrm{GB}_{\text {app }}$ ) not the observed $\mathrm{HSO}_{4}{ }^{-}$departure. Instead, this $\mathrm{HSO}_{4}{ }^{-}$was attached to a protonated carboxylate site that had a $\mathrm{GB}_{\text {app }}$ slightly higher than $\mathrm{HSO}_{4}^{-}$. Not only is the GB of the departing $\mathrm{HSO}_{4}^{-}$lower than the $\mathrm{GB}_{\text {app }}$ of the corresponding carboxylate site, but also, compared with the (second) $\mathrm{HSO}_{4}^{-}$that remains, the departing $\mathrm{HSO}_{4}^{-}$is less well matched with the $\mathrm{GB}_{\text {app }}$ of the carboxylate site to which it was bound. If one considers that the remaining $\mathrm{HSO}_{4}{ }^{-}$ leaves as $\mathrm{H}_{2} \mathrm{SO}_{4}$ to form [[Glu] Fibrinopeptide $\left.\mathrm{B}-\mathrm{H}\right]^{-}$ (Figure $3 \mathrm{~b}$ ), then it becomes clear that this second $\mathrm{HSO}_{4}^{-}$ was attached to a more acidic carboxylic acid. The data shows that $\mathrm{HSO}_{4}{ }^{-}$only has sufficient basicity to pull off one proton from the more acidic of the two carboxylic acid sites where attachment had occurred. Note that Scheme 1 omits the possibility that anion attachment occurs at a protonated amino site. Evidence supporting this omission is given by the fact that $\mathrm{HSO}_{4}{ }^{-}$departure is the first loss from [[Glu] Fibrinopeptide $\left.\mathrm{B}+2 \mathrm{HSO}_{4}\right]^{2-}$. As explained above, had $\mathrm{HSO}_{4}^{-}$been attached to a protonated amino site, $\mathrm{H}_{2} \mathrm{SO}_{4}$ loss should have occurred instead. For the other anions that all have GBs higher than $\mathrm{HSO}_{4}{ }^{-}$, surviving adducts (wherein the number of attached anions is equal to or less than the charge state) are even less likely to exhibit attachment at a protonated amino group because the GB matching of the "proton bound mixed dimer" constituting the adduction site becomes even less favorable.

By contrast, fragmentation of the $\mathrm{Br}^{-}$adduct is simple; all $\mathrm{Br}^{-}$in both [[Glu] Fibrinopeptide $\left.\mathrm{B}-\mathrm{H}+\mathrm{Br}\right]^{2-}$ (Figure 3c) and [[Glu] Fibrinopeptide $\mathrm{B}+2 \mathrm{Br}]^{2-}$ (Figure 3d) will depart as $\mathrm{HBr}$, leading ultimately to $[[\mathrm{Glu}] \text { Fibrinopeptide } \mathrm{B}-2 \mathrm{H}]^{2-}$, i.e., the $\mathrm{GB}$ of $\mathrm{Br}^{-}$(higher than that of $\mathrm{HSO}_{4}^{-}$) is now capable of pulling off both protons from the two sites of attachment. Clearly, when two $\mathrm{Br}^{-}$anions are attached, the one attached to the more acidic carboxylic acid will be more prone to $\mathrm{HBr}$ loss (Scheme 1, middle column). Notably, the $\mathrm{GB}$ of $\mathrm{Br}^{-}$is not high enough to form a stable adduct at the third most acidic carboxylic acid. However, the higher GB of $\mathrm{Cl}^{-}$does permit formation of the triply adducted [[Glu] Fibrinopeptide $\mathrm{B}+3 \mathrm{Cl}]^{3-}$. The order of consecutive dissociations of $[[\mathrm{Glu}] \text { Fibrinopeptide } \mathrm{B}+3 \mathrm{Cl}]^{3-}$ precursors 

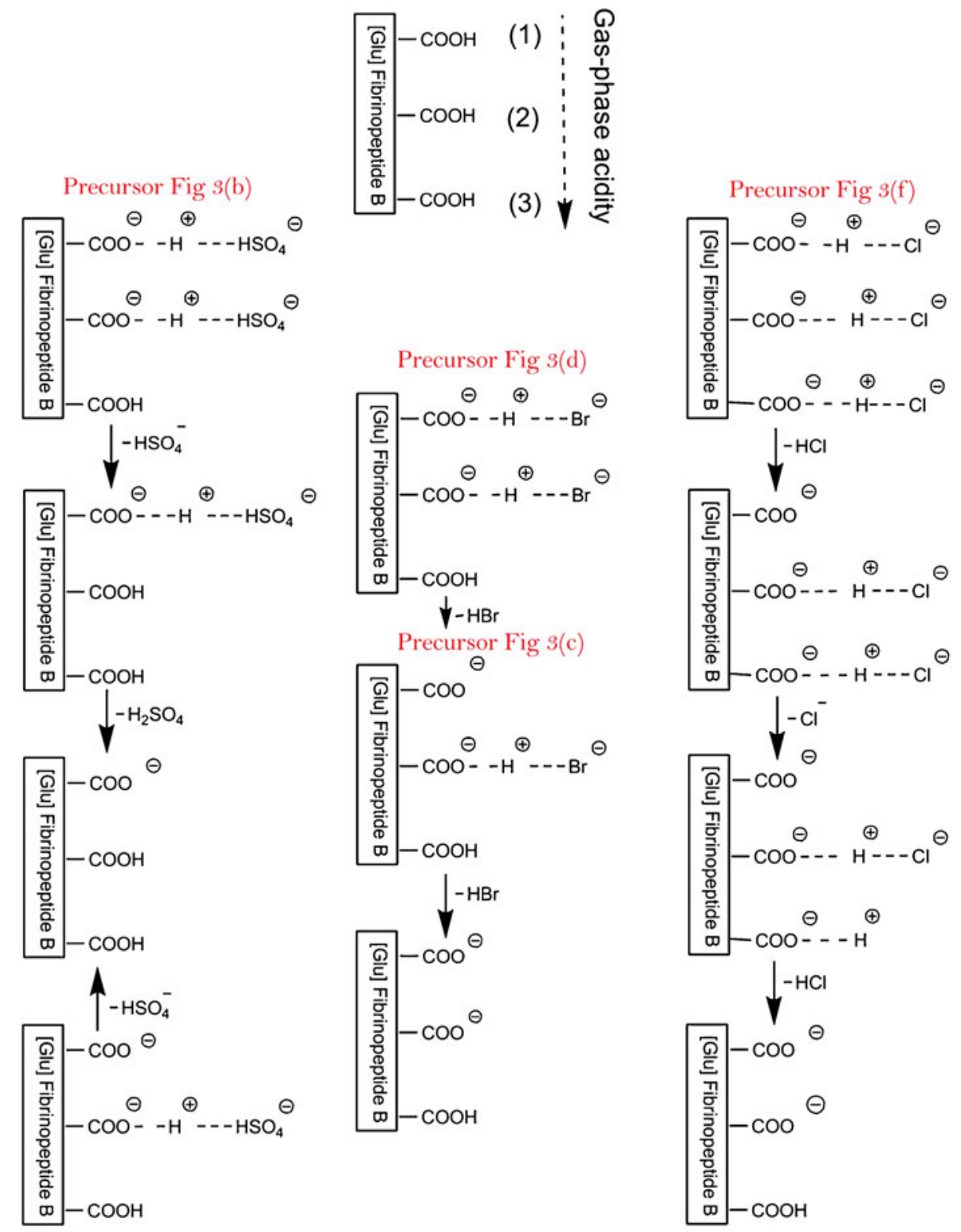

Precursor Fig 3(a)

Scheme 1. Fragmentation pathways of $\mathrm{HSO}_{4}{ }^{-}, \mathrm{Br}^{-}$, and $\mathrm{Cl}^{-}$adducts of [Glu] Fibrinopeptide $\mathrm{B}$. The three most acidic sites on the [Glu] Fibrinopeptide B backbone are shown schematically with attached anions. The gas-phase acidities of these carboxylic acids decrease in descending from top to bottom as marked in top center schematic. The GBs of the anions increase in the order $\mathrm{HSO}_{4}^{-}<\mathrm{Br}^{-}<\mathrm{Cl}^{-}$. Whether an anion departs with or without a proton depends upon the relative $\mathrm{GBs}$ of the anion versus the carboxylate group to which the proton is attached. At a given carboxylate site $\mathrm{HSO}_{4}{ }^{-}$is more prone to depart than $\mathrm{Br}^{-}$and much more so than $\mathrm{Cl}^{-}$. $\mathrm{Cl}^{-}$departure, however, was observed, but only from a higher $\mathrm{GB}$ carboxylate site (third site from top in diagram) that was mismatched with the lower $\mathrm{GB}_{\text {of }} \mathrm{HSO}_{4}{ }^{-}$, hence no $\mathrm{HSO}_{4}{ }^{-}$adduct could form at this site. The rationalization for omitting anion attachment to potentially protonated amino sites is given in the text. The possibility for salt bridge formation exists, but is not shown in this diagram

can be deduced from the MS/MS product ion spectrum (Figure $3 \mathrm{f}$ ). The fact that $[[\mathrm{Glu}] \text { Fibrinopeptide } \mathrm{B}+2 \mathrm{Cl}]^{2-}$ was hardly observed provides evidence that the preferred first step in decomposition is loss of $\mathrm{HCl}$ (not $\mathrm{Cl}^{-}$ departure). Clearly this $\mathrm{HCl}$ loss is most favored from the most acidic carboxylic acid (Scheme 1, right column). The $[[\mathrm{Glu}] \text { Fibrinopeptide } \mathrm{B}-\mathrm{H}+2 \mathrm{Cl}]^{3-}$ ion that is thus formed then decomposes to $\mathrm{Cl}^{-}$and $[[\mathrm{Glu}]$ Fibrinopeptide $\mathrm{B}-\mathrm{H}+$ $\mathrm{Cl}^{2-}$ with no loss of $\mathrm{HCl}$ (no [[Glu] Fibrinopeptide $\mathrm{B}-2 \mathrm{H}+$ $\mathrm{Cl}]^{3-}$ was formed). As was the case for $\mathrm{HSO}_{4}^{-}$above, $\mathrm{Cl}^{-}$ loss is most favored at the carboxylate site of highest $\mathrm{GB}_{\mathrm{app}}$, where the proton remains (Scheme 1, right column). The fact that the $[[\mathrm{Glu}] \text { Fibrinopeptide } \mathrm{B}-2 \mathrm{H}+\mathrm{Cl}]^{3-}$ peak was not observed in either Figure $3 \mathrm{f}$ or Figure $1 \mathrm{f}$ can be rationalized 
if we consider that $[[\mathrm{Glu}] \text { Fibrinopeptide } \mathrm{B}-2 \mathrm{H}+\mathrm{Cl}]^{3-}$ has a higher $\mathrm{GB}_{\text {app }}$ than $\mathrm{Cl}^{-}$. Thus, two protons of the three binding sites on $[[\mathrm{Glu}] \text { Fibrinopeptide } \mathrm{B}+3 \mathrm{Cl}]^{3-}$ can be abstracted by $\mathrm{Cl}^{-}$.

\section{A New Model for Anion Attachment to [Glu] Fibrinopeptide B-Negative Ion Model}

Scheme 2 shows a schematic of a proposed new model for anion attachment to [Glu] Fibrinopeptide B [19]. As solvent evaporates from the droplets, the ammonium salt concentration increases. The anions in solution will be attracted by the neutral acidic sites $(-\mathrm{COOH})$, thus forming $\mathrm{R}^{-\mathrm{COO}^{-} \cdots}$ $\mathrm{H}^{+} \cdots \mathrm{A}^{-}$or by the protonated basic sites $\left(-\mathrm{NH}_{3}^{+}\right)$giving rise to $\mathrm{R}^{-} \mathrm{NH}_{2} \cdots \mathrm{H}^{+} \cdots \mathrm{A}^{-}$. As the last solvent molecules depart from the complex, charged molecules possess a certain amount of rotational-vibrational energy and electrostatic repulsion between negative charges increases. These factors cause low-energy dissociation(s) of charged complexes meaning that anions or protonated anions will depart from these complexes until only proton-bound mixed dimers of anions that have well-matched GBs on the two sides of the central proton remain. The key to our new model is that only stable adducts survive to the detector. An attached anion is only stable when it has a GB close to the $\mathrm{GB}_{\text {app }}$ of the deprotonated site at which it is attaching. In other words, both anions in the proton-bound mixed dimer must exert an approximately equal pull on the central proton. For various

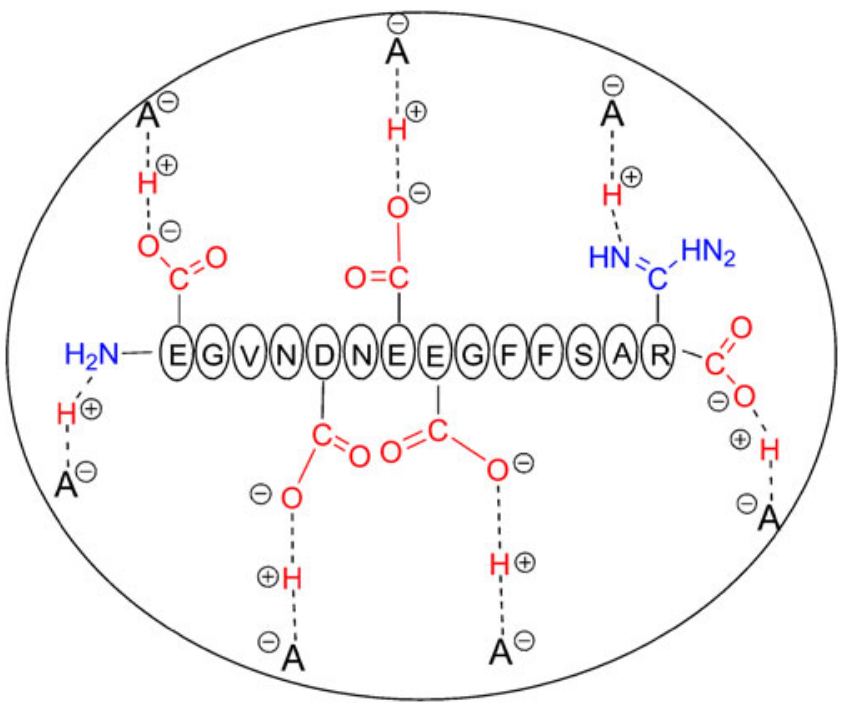

Scheme 2. [Glu] Fibrinopeptide B complex formed in a negatively charged electrospray droplet near the end of the droplet's lifetime. Anions are attracted to the protonated basic sites and acidic sites on [Glu] Fibrinopeptide B before the final solvent departs from the peptide. Capital letters indicate amino acid and $A^{-}$indicates negatively charged anion. Omitted from the diagram for increased visual clarity is the possibility for salt bridge formation. In addition to ammonium-carboxylate interactions, salt bridges can take the form of $A^{-}$linked ammonium and carboxylic acid groups carboxylate or amino sites on the peptide/protein, the anion fulfilling this requirement will not be the same.

\section{Evidence Supporting the Model}

In our experiments, low $\mathrm{GB}$ anions such as $\mathrm{HSO}_{4}{ }^{-}$, are best matched with low $\mathrm{GB}_{\text {app }}$ sites of both analytes, i.e., singly deprotonated or doubly deprotonated peptide forms bearing higher acidity protons. There are two basic amino/imino sites in [Glu] Fibrinopeptide B that are both protonated at near-neutral $\mathrm{pH}$ and both sites can interact with $\mathrm{HSO}_{4}^{-}$. The attachment of $\mathrm{HSO}_{4}^{-}$to protonated basic sites is virtually equivalent to a neutral $\mathrm{H}_{2} \mathrm{SO}_{4}$ attaching to that vacant basic site. If the $\mathrm{GB}_{\text {app }}$ of a carboxylate site that is deprotonated is far higher than the $\mathrm{GB}$ of $\mathrm{HSO}_{4}^{-}, \mathrm{HSO}_{4}^{-}$cannot form a stable adduct at that site on the peptide. From the spectrum of Figure 1b, the highest charge state adduct formed by $\mathrm{HSO}_{4}^{-}$attachment is -2 , which indicates that the maximum number of $\mathrm{HSO}_{4}{ }^{-}$anions attached to the acidic sites is two. If one adds the two neutral $\mathrm{H}_{2} \mathrm{SO}_{4}$ molecules attached at the two most basic amino sites (arginine and N-terminus), the total number of sites for attachment is four, and four adducted bisulfates were indeed observed to be formed at -2 charge state. When an anion has attached to every carboxylic acid where there is a reasonably close match of the GBs on the two sides of the proton, and when an anion has attached to every protonated amino group, then, according to our model, the maximum amount of anion attachment has occurred. From this maximally adducted state, as the last solvent molecules depart when the ion enters the gas phase, $\mathrm{HSO}_{4}^{-}$or $\mathrm{H}_{2} \mathrm{SO}_{4}$ can depart from these sites, especially if there is a significant difference in the GBs of the two sides of the proton-bound mixed dimers, thus producing [[Glu] Fibrinopeptide $\left.\mathrm{B}-\mathrm{H}+\mathrm{HSO}_{4}\right]^{2-}$ and other [[Glu] Fibrinopeptide $\mathrm{B}+$ $\left.\mathrm{nHSO}_{4}+\mathrm{mH}_{2} \mathrm{SO}_{4}\right]^{n-}$ species $(n=1,2 ; \mathrm{m}=0,1,2$ where $\mathrm{n}+$ $\mathrm{m}=3$ or less). Depicted in Scheme $3 \mathrm{a}$ is the rationale explaining the observed reactivity of the maximally adducted $\left[[\mathrm{Glu}] \text { Fibrinopeptide } \mathrm{B}+2 \mathrm{HSO}_{4}+2 \mathrm{H}_{2} \mathrm{SO}_{4}\right]^{2-}$. $\mathrm{HSO}_{4}^{-}$loss from the second most acidic carboxylic acid is a favored low-energy pathway. $\mathrm{H}_{2} \mathrm{SO}_{4}$ loss from weak attachment at the second highest basicity amino group, followed by a second $\mathrm{H}_{2} \mathrm{SO}_{4}$ loss from the most basic amino group, also occur readily. The last remaining site of adduction is at the most acidic carboxylic acid which offers a carboxylate GB most closely matched to $\mathrm{HSO}_{4}^{-}$.

The behavior of anions that are observed to produce only -2 charge state adducts such as $\mathrm{NO}_{3}{ }^{-}$and $\mathrm{Br}^{-}$can be rationalized by considering that these anions can easily pull off the most acidic proton from neutral [Glu] Fibrinopeptide B. This means that their GBs are significantly higher than that of $[[\mathrm{Glu}]$ Fibrinopeptide $\mathrm{B}-\mathrm{H}]^{-}$, and this is the reason that these anions cannot form stable -1 charge state complexes. Doubly deprotonated peptides are readily formed, however, and because there is a better match with the $\mathrm{GB}_{\text {app }}$ of [[Glu] Fibrinopeptide $\mathrm{B}-2 \mathrm{H}]^{2-}$, [[Glu] Fibrinopeptide $\left.\mathrm{B}-\mathrm{H}+\mathrm{A}\right]^{2-}$ (where $\mathrm{A}$ represents $\mathrm{NO}_{3}^{-}$or $\mathrm{Br}^{-}$) ions are also formed. Stable adducts are thus formed as proton-bound mixed dimers with 
(a) $\left[[\mathrm{Glu}] \text { Fibrinopeptide } \mathrm{B}+2 \mathrm{HSO}_{4}+2 \mathrm{H}_{2} \mathrm{SO}_{4}\right]^{2-}$

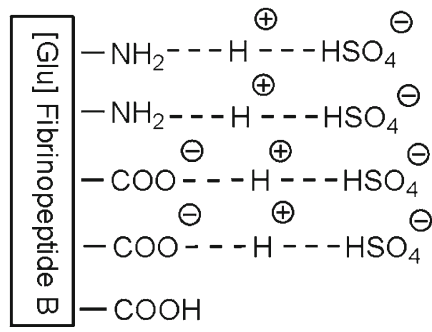

(4) Best matched site

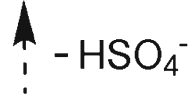

(b) [[Glu] Fibrinopeptide $\mathrm{B}+2 \mathrm{Br}+2 \mathrm{HBr}]^{2-}$

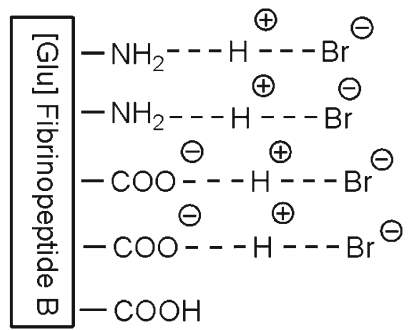

(4) Best matched site

\section{(c) $[[\mathrm{Glu}] \text { Fibrinopeptide } \mathrm{B}+3 \mathrm{Cl}+2 \mathrm{HCl}]^{3-}$}
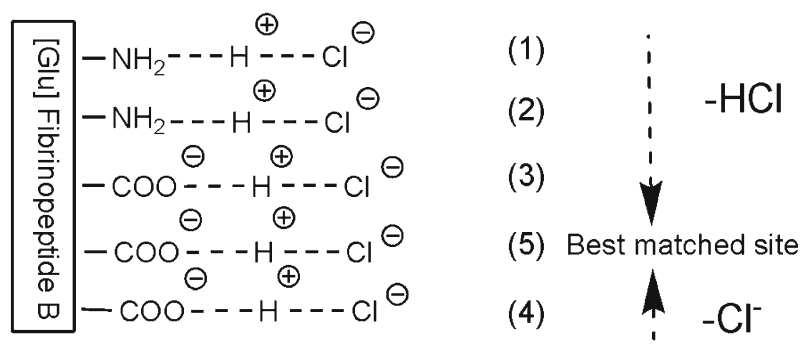

Scheme 3. Maximum number of anions attached and their decomposition pathways for: (a) $\mathrm{HSO}_{4}{ }^{-}$, (b) $\mathrm{Br}^{-}$, and (c) $\mathrm{Cl}^{-}$ adducts of [Glu] Fibrinopeptide $B$ in the gas-phase. The top amino group is the lower GB amino group of the two that are shown. The gas-phase acidities of the carboxylic acid groups decrease from top to bottom. (1), (2), (3), (4), and (5) indicate the order of decomposition as deduced from Figure 3. Dashed arrow indicates the decomposition direction leading to the best matched site. Adducts above the best matched site tend to decompose by losing neutrals; below, they dissociate by losing anions

carboxylate anions that are not the least basic of the peptide, i.e., the most acidic carboxylic acid is deprotonated, and the adduct forms at a second carboxylic acid of lower acidity.

An even higher anion GB is required to enable attachment of a third anion. Up to three $\mathrm{Cl}^{-}$can attach to [Glu] Fibrinopeptide B to form [[Glu] Fibrinopeptide $\mathrm{B}+3 \mathrm{Cl}]^{3-}$. For much higher GB anions such as $\mathrm{F}^{-}$, no adducts at all were observed. This result is rationalized by considering that the $\mathrm{GB}$ of $\mathrm{F}^{-}$is significantly higher than the highest $\mathrm{GB}_{\text {app }}$ [[Glu] Fibrinopeptide $\mathrm{B}-3 \mathrm{H}]^{3-}$ formed by triply deprotonated [Glu] Fibrinopeptide B. This implies that there is a mismatch between triply deprotonated [Glu] Fibrinopeptide $\mathrm{B}$ and $\mathrm{F}^{-}$and that a proton bound mixed dimer of the two would dissociate rapidly to $\mathrm{HF}$ and [[Glu] Fibrinopeptide B $-3 \mathrm{H}]^{3-}$.

\section{Mixed Dimers of Proton-Bound Anions}

Additional evidence for the proposed model comes from experiments performed using [Glu] Fibrinopeptide B in combination with mixtures of anions. Shown in Figure $4 \mathrm{a}$ is an example employing equimolar chloride and iodide simultaneously. Mirroring the single anion results shown in Figure 1, iodide (lower GB) forms only singly and doubly charged adducts, whereas chloride (higher GB) forms only doubly and triply charged adducts. This behavior can be rationalized by considering that iodide attaches at the two most acidic carboxylic acids and its GB is adequately matched with those of the corresponding two weakest $\mathrm{GB}_{\text {app }}$ carboxylate groups. In contrast, the GB of chloride is not well matched with the carboxylate corresponding to the highest acidity proton (no [[Glu] Fibrinopeptide $\mathrm{B}+\mathrm{Cl}]^{-}$ observed), but instead, it forms stable adducts with the second and third most acidic protons, i.e., [Glu] Fibrinopeptide $\mathrm{B}-\mathrm{H}+2 \mathrm{Cl}]^{3-}$. Interestingly, peaks corresponding to [[Glu] Fibrinopeptide B $+3 \mathrm{Cl}]^{3-}$, [[Glu] Fibrinopeptide B + $3 \mathrm{Cl}+\mathrm{HCl}]^{3-}$, and $[[\mathrm{Glu}] \text { Fibrinopeptide } \mathrm{B}+3 \mathrm{Cl}+2 \mathrm{HCl}]^{3-}$ were observed. The presence of these latter peaks indicates that, despite the fact that $[[\mathrm{Glu}] \text { Fibrinopeptide } \mathrm{B}+\mathrm{Cl}]^{-}$was not formed indicating a mismatch of the $\mathrm{GBs}$ of $\mathrm{Cl}^{-}$and the carboxylate bearing the most acidic proton, when the second and third most acidic protons are each holding $\mathrm{Cl}^{-}$, the $\mathrm{GB}_{\text {app }}$ of the site holding the most acidic proton has been altered sufficiently so that it now can accommodate a third $\mathrm{Cl}^{-}$. Thus, attachment of the first two anions apparently alters the balance of GBs at the most acidic carboxylic acid compared with when no other anions are attached to the peptide. We attribute this alteration to a combination of a weak inductive effect, which may slightly raise the intrinsic GB of the implicated carboxylate and Coulomb repulsion that increases $\mathrm{GB}_{\text {app }}[20-22]$ of the anionic peptide. These effects combine to produce a better matching of GBs at this site as compared with the situation when no other $\mathrm{Cl}^{-}$anions are attached elsewhere. As depicted in Scheme 3c, a maximum of five $\mathrm{Cl}^{-}$can be carried by a single [Glu] Fibrinopeptide B molecule, with a maximum charge of -3 . Those $\mathrm{HCls}$ that are held by amino groups are the ones that depart the most easily, followed by the $\mathrm{HCl}$ at the weakest basicity carboxylate. Afterwards, $\mathrm{Cl}^{-}$may depart form the third most acidic carboxylic acid, leaving the one remaining $\mathrm{Cl}^{-}$ attached to the second most acidic carboxylic acid as the most stable site of adduction, meaning that the corresponding carboxylate is best matched with $\mathrm{Cl}^{-}$.

Figure $4 \mathrm{~b}$ shows the appearance of so-called mixed anionic adducts of [Glu] Fibrinopeptide B from a solution containing an equimolar combination of bromide and bisulfate anions. Mixed adducts are comprised of two 


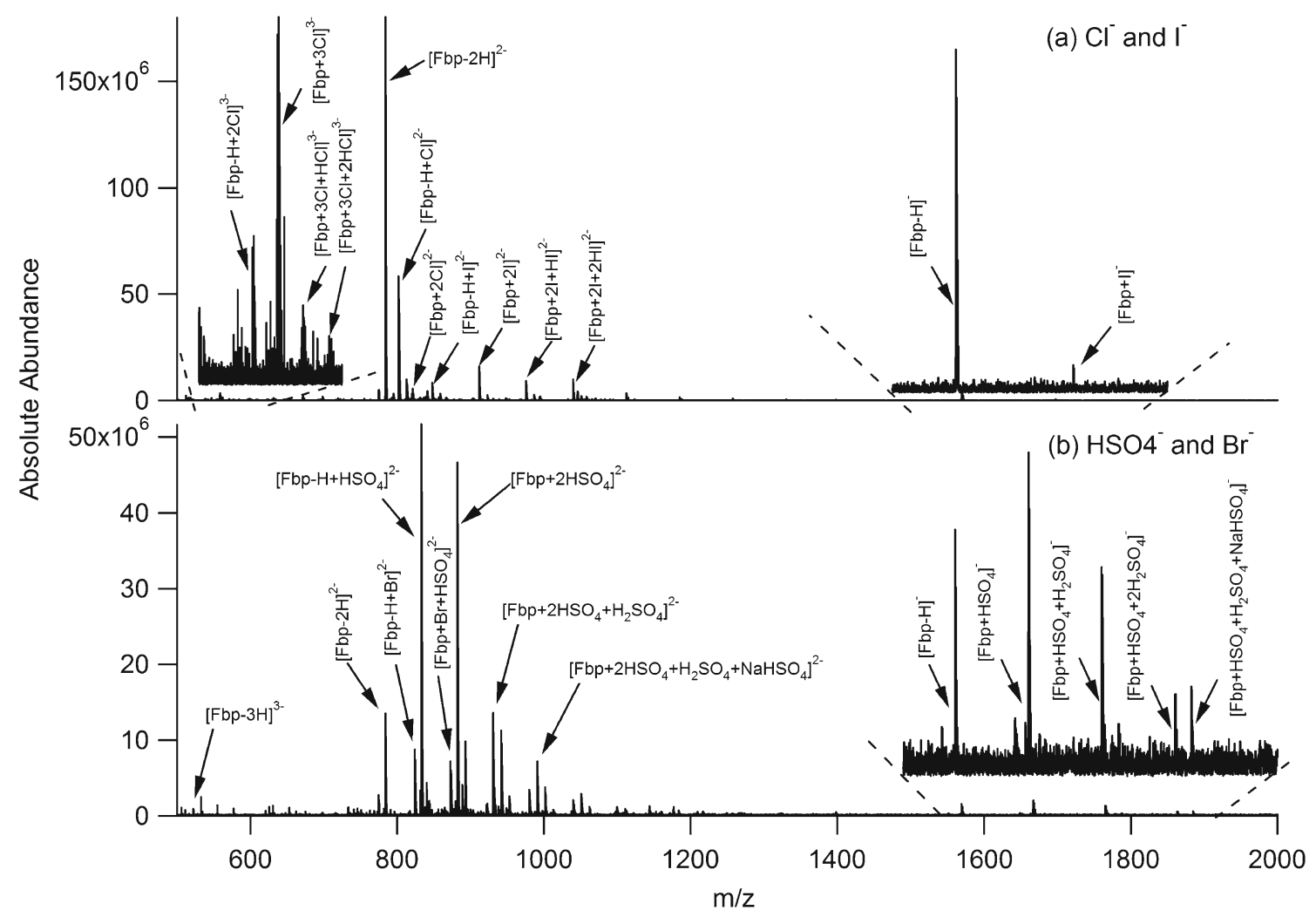

Figure 4. ES mass spectra of solutions containing 3.2 $\mu \mathrm{M}$ [Glu] Fibrinopeptide $\mathrm{B}$ (abbreviated Fbp) along with binary mixtures of anions: (a) $32 \mu \mathrm{M} \mathrm{NH}{ }_{4} \mathrm{Cl}$ and $32 \mu \mathrm{M} \mathrm{NH} \mathrm{N}_{4}$; (b) $32 \mu \mathrm{M} \mathrm{NH} \mathrm{HSO}_{4}$ and $32 \mu \mathrm{M} \mathrm{NH} \mathrm{H}_{4} \mathrm{Br}$

different anions that are attached simultaneously to the analyte. If, according to the model, mixed anions are to be stable, then attachment of the component anions of different GBs must occur at properly corresponding carboxylic acid sites. The most stable form of [[Glu] Fibrinopeptide $\mathrm{B}+\mathrm{Br}$ $\left.+\mathrm{HSO}_{4}\right]^{2-}$ occurs when $\mathrm{HSO}_{4}^{-}$is attached to the highest acidity proton and $\mathrm{Br}^{-}$is simultaneously attached to the proton of second highest acidity. Identification of the favored routes of decomposition from mixed adducts can become complicated because the site of attachment where the GBs of the component anions are least well matched may not be easy to discern. The favored route of decomposition of the precursor [[Glu] Fibrinopeptide $\mathrm{B}+\mathrm{Br}+$ $\left.\mathrm{HSO}_{4}\right]^{2-}$ mixed adduct was loss of $\mathrm{HBr}$, thus forming [[Glu] Fibrinopeptide $\left.\mathrm{B}-\mathrm{H}+\mathrm{HSO}_{4}\right]^{2-}$ (data not shown). Similar to the situation described in the preceding paragraph for $\mathrm{Cl}^{-}$ attachment, single attachment to form [[Glu] Fibrinopeptide $\mathrm{B}+\mathrm{Br}]^{-}$was not detected, whereas [Glu] Fibrinopeptide B + $2 \mathrm{Br}]^{2-}$ was observed in Figure 1e (and in Figure $4 \mathrm{~b}$ in low abundance). Analogous to the description above, this implies that the attachment of $\mathrm{Br}^{-}$to the second most acidic carboxylic acid has slightly strengthened the intrinsic GB of the carboxylate bearing the most acidic proton by a weak inductive effect. In addition, Coulomb repulsion from the first attachment increases $\mathrm{GB}_{\text {app }}$ of the lowest $\mathrm{GB}_{\text {app }}$ carboxylate site on the peptide. Thus, the combination of these effects apparently improves the matching of the second $\mathrm{Br}^{-}$at this most acidic carboxylic acid. Here the maximum number of attached bromides is 4, for the ion [[Glu] Fibrinopeptide $\mathrm{B}+2 \mathrm{Br}+2 \mathrm{HBr}]^{2-}$ shown schematically in Scheme $3 b$. From this maximally adducted form, two $\mathrm{HBr}$ molecules are readily lost forming [[Glu] Fibrinopeptide B + $2 \mathrm{Br}]^{2-}$ (Figure 3e). Afterwards, $\mathrm{HBr}$ loss from the most acidic carboxylic acid site can occur leaving the second most acidic carboxylic acidic as the site of most stable $\mathrm{Br}^{-}$ attachment.

\section{Attributes of the Negative Ion Model for Multiple Anion Attachment}

The attributes of the negative ion model can be summarized as (1) the carboxylate groups are much more basic than available amino groups. For all the anions tested, binding occurs at carboxylic acid sites in preference to protonated amino sites. This is evidenced by the fact that even for the lowest $\mathrm{GB}$ anion tested, $\mathrm{HSO}_{4}^{-}$, the doubly adducted ion [[Glu] Fibrinopeptide $\left.\mathrm{B}+2 \mathrm{HSO}_{4}\right]^{2-}$ decomposes in a first step by $\mathrm{HSO}_{4}^{-}$departure. If one attachment had instead occurred at a lower $\mathrm{GB}_{\text {app }}$ (protonated) amino group, then $\mathrm{H}_{2} \mathrm{SO}_{4}$ loss would have been expected, but was not observed. For the higher GB anions, clearly carboxylate anions provide a better matching of $\mathrm{GB}_{\text {app }}$ than neutral 
amino sites, hence, the former are the sites involved in stable anionic adduct formation; (2) apparent GBs of the carboxylate groups on the peptides are deduced to be close to one another. This is evidenced by the fact that three of the same type of anions can attach simultaneously to one peptide. Stable attachment of three of the same anions at different sites would not be possible if the sites were not of comparable basicity. Moreover, in the few cases where two different anions added to the same peptide (e.g., Figure 4b), the anions were typically not far apart in GB; (3) apparent GBs of the individual carboxylate and amino sites do not behave independently of one another. Rather, anion attachment or removal of a proton at a particular site can raise the intrinsic GBs of other sites by exerting a weak inductive effect. Furthermore, Coulomb repulsion caused by this prior charged site creation can raise $\mathrm{GB}_{\mathrm{app}}$ of other carboxylate sites on the peptide that are holding protons. Attachment of an anion at a protonated amino group (thus forming an overall neutral site), however, does not significantly alter the apparent GBs of other potential binding sites.

\section{Positive Ion Model}

An analogous model can be constructed for adduct formation in the positive ion mode. For positive mode adduct formation, excess cations, e.g., protons, will be attracted to basic sites on the peptide and form $\mathrm{R}-\mathrm{NH}_{2} \cdots \mathrm{H}^{+}$. For some of these protonated basic sites, nearby anions may form R$\mathrm{NH}_{2} \cdots \mathrm{H}^{+} \cdots \mathrm{A}^{-}$. According to our model, the latter type of adduct will be especially stable when the amino group and the attaching anion have closely matched GBs. This type of attachment is virtually equivalent to a neutral molecule binding to a vacant basic site. Analogous to the situation for negative ions noted in the last paragraph above, compared with charging, the attachment of neutral molecule(s) to a peptide/protein will hardly change $\mathrm{GB}_{\text {app }}$ of other sites on the peptide/protein. This implies that if several sites on the peptide/protein were of comparable basicity, a particular acid could be found that would be able to attach multiple times as a neutral molecule at various basic sites on the peptide/protein. This model is supported by important results from Williams and coworkers [23, 24], who added $\mathrm{HClO}_{4}$ to peptides/proteins in solution in order to determine the number of basic sites in these peptides/proteins. According to our model, the success of this method arises from the advantageous matching of the $\mathrm{GB}$ of $\mathrm{ClO}_{4}^{-}$with $\mathrm{GB}_{\text {app }}$ of the typical amino site on a peptide/protein. If indeed, all of the amino sites have apparent GBs that are adequately matched with $\mathrm{ClO}_{4}^{-}$, each basic amino group may hold a stable adducted $\mathrm{HClO}_{4}$ molecule. As recognized by the Williams group [23, 24], this allows the calculation of the number of basic sites from an assessment of the maximum number of $\mathrm{HClO}_{4}$ molecules attached (each one a neutral site) plus the number of protonated sites (equal to the charge state of the protein/peptide). The success of this method hinges upon the ability to either protonate or form a stable
$\mathrm{HClO}_{4}$ adduct at every basic site. Our model of adduct attachment contends that progressive addition of neutral molecules does not significantly alter the apparent GBs of other sites on the peptide/protein. However, as stated above for the negative ion model, when the charge state at one site changes, apparent GBs at other sites are affected. In the positive ion case, raising the charge at one site will lower the intrinsic GBs of other distant sites [via the inductive effect (weak)] and lower $\mathrm{GB}_{\text {app }}$ by Coulomb repulsion. This alteration of apparent GBs at amino sites can throw off the balance in GBs that held $\mathrm{HClO}_{4}$ at a particular site, leading to a breakdown of the method enabling calculation of the number of basic sites. This aspect of our model can account for why lower charge states are required to determine the basic sites on peptide/protein using $\mathrm{HClO}_{4}$ adducts. In considering alternatives to $\mathrm{ClO}_{4}^{-}$, which has an extremely low GB (1180 $\pm 59 \mathrm{~kJ} / \mathrm{mol})$ [15], Stephenson and McLuckey $[25,26]$ used a higher GB anion, $\mathrm{I}^{-}$, introduced as $\mathrm{HI}$ in a quadrupole ion trap to determine the number of basic sites on peptides/proteins. These experiments were successful at this endeavor when the gas-phase acidity of the analyte peptide was low $\left(<\sim 1380 \mathrm{~kJ} \mathrm{~mol}^{-1}\right)$, but as can be explained by our model, higher gas-phase acidity peptides could not stabilize $\mathrm{I}^{-}$adducts, and the result is that not all $\mathrm{HI}$ molecules remain attached, hence the ability to determine the number of basic sites is compromised. If even higher GB anions, such as $\mathrm{CH}_{3} \mathrm{COO}^{-}$, were used, then virtually no adducts would form in positive mode for peptides/proteins.

The attributes of the positive ion model can be summarized as (1) binding of a neutral at an amino site will polarize this amino group somewhat, but hardly change the apparent GBs of other sites; (2) augmenting the charge state by adding a proton (with no counterion) at one site can decrease the instrinsic GBs of other sites (weak inductive effect) and lower the $\mathrm{GB}_{\text {app }}$ of the peptide by Coulomb repulsion.

\section{Reciprocal Stabilization of Opposite Charges and Salt Bridge Formation}

Intentionally left out of Scheme 2 for purposes of increased visual clarity is the possibility of salt bridge formation. Salt bridges, comprised of ionic bonds linking carboxylate sites and protonated amino groups have been reported upon in the literature [27]. They arise when charges opposite to that of the overall charge are stabilized by nearby charge sites corresponding to the excess charges (Scheme 4a). In larger proteins, this has been referred to as "reciprocal stabilization of opposite charges" [28, 29]. Thus, in the negative-ion mode, protonated amino sites are likely to be stabilized by the negatively charged carboxylate sites, thus preventing proton departure from these basic sites (Scheme 4a). Similarly, in the positive-ion mode, negatively charged carboxylate groups are likely to be situated near protonated amino sites. The concept of the salt bridge pertains to our negative ion model because there exists the possibility for 

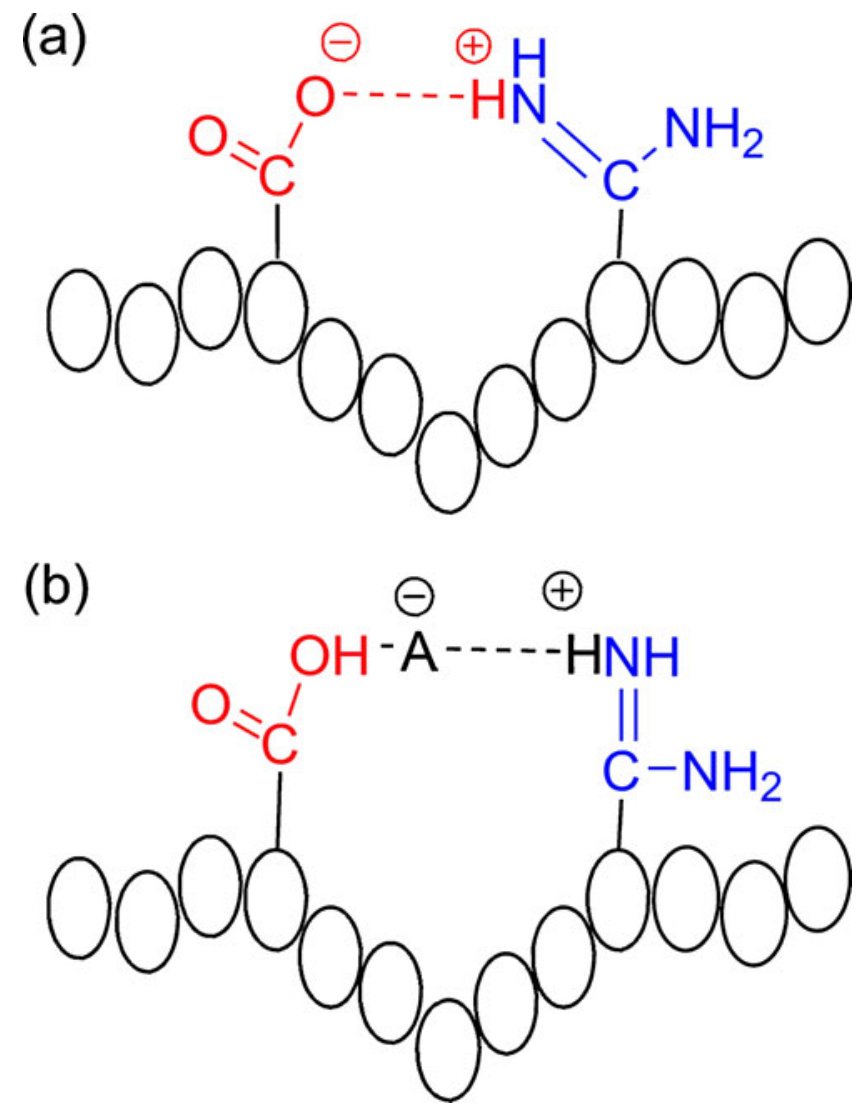

Scheme 4. Schematic of two generic types of salt bridges: (a) direct formation between carboxylate and basic site with bridging proton; (b) involving a bridging anion. Both types

salt bridge formation between neighboring carboxylic acid and protonated amino sites that are linked by a central attaching anion (Scheme $4 b$ ). Formation of a salt bridge of this type will (1) result in an overall neutral charge at the salt bridge even though the anion has successfully attached; (2) create an exceptional case where the (shared) anion is electrostatically linked to a protonated amino group (not shown in Schemes 1, 2, or 3). In the positive ion model, salt bridge formation is also possible and, if present, it will contribute to a lowering of charge states.

\section{Conclusion}

The observed change in the predominating anion in adducts with shifting peptide charge state appears to be correlated to the extent of matching between the GB of the attaching anion and the $\mathrm{GB}_{\text {app }}$ of the deprotonated peptide at the site of attachment. During the process of negative ion electrospray, lower GB anions match with lower charge state peptide ions, whereas higher GB anions match with higher charge state peptide ions. Adduct stability decreases when there is a mismatch in GBs of the two anions constituting the proton-bound mixed dimer of anions. Mismatched attach- ment sites are subject to high rates of decomposition. Knowledge of adduct behavior can enable a degree of control over adduct formation at various charge states in ESMS studies.

\section{Acknowledgments}

The authors acknowledge financial support for this research by the National Science Foundation through CHE-1058764.

\section{Appendix - Thermodynamic Considerations}

\section{Trends in Gas-Phase Basicities of Carboxylic Acids}

For straight-chain mono-carboxylic acids of the form $\mathrm{CH}_{3}\left(\mathrm{CH}_{2}\right)_{n} \mathrm{COOH}(n=0,1,2,3,4)$, the $\mathrm{GB}$ of the deprotonated acid falls in the range of $1418.5 \pm 9.6 \mathrm{~kJ} / \mathrm{mol}$ to $1428.7 \pm 8.4 \mathrm{~kJ} / \mathrm{mol}$ [15]. However, if the terminal $\mathrm{CH}_{3}$ group is transformed into a second $\mathrm{COOH}$ group, the corresponding deprotonated dicarboxylic acids have substantially lower GBs that range from $1318.0 \pm 0.12 \mathrm{~kJ} / \mathrm{mol}$ to $1342.28 \pm 0.12 \mathrm{~kJ} / \mathrm{mol}$ [30]. Glutamic acid and aspartic acid are the two amino acids that have two $-\mathrm{COOH}$ groups in their free amino acid structures and the GBs of the corresponding singly deprotonated anions are $1348 \pm 21 \mathrm{~kJ} /$ $\mathrm{mol}$ and $1345 \pm 14 \mathrm{~kJ} / \mathrm{mol}$, respectively [31]. Extending the trend, we can expect that more glutamic/aspartic amino acids included in a peptide sequence will further lower the GB of the corresponding singly deprotonated form. This reasoning can rationalize why it is possible to observe stable bisulfate $(1265.0 \pm 10.0 \mathrm{~kJ} / \mathrm{mol})$ attachment to the neutral or singly charged peptides employed in this study, whereas acetate $(1428.7 \pm 8.4 \mathrm{~kJ} / \mathrm{mol})$ could not form a stable adduct.

\section{Apparent Gas-Phase Basicity Versus Intrinsic Gas-Phase Basicity}

Within this paper in negative ion descriptions, anion GB represents $-\Delta \mathrm{G}^{\circ}$ of the reaction $\mathrm{B}^{-}+\mathrm{H}^{+} \rightarrow \mathrm{BH}$. Furthermore, the term "apparent gas-phase basicity" abbreviated as "GB app" has been employed to describe the gas-phase basicities of multiply charged peptides. An apparent GB differs from an intrinsic (Brønsted-Lowry) GB because the accumulated electrostatic attraction (Coulomb energy) of like-charged anionic sites toward protons must be factored in. Thus, if a given carboxylic acid site is deprotonated, a second carboxylic acid site on the same molecule holds more tightly its proton. The apparent GB of this latter site is thus the intrinsic GB plus the additional Coulomb energy, $\delta$ [32]:

$$
\mathrm{GB}_{\mathrm{app}}\left([\mathrm{M}-\mathrm{nH}]^{\mathrm{n}-}\right)=\mathrm{GB}\left([\mathrm{M}-\mathrm{nH}]^{\mathrm{n}-}\right)+\delta
$$


For a generic proton-bound anionic adduct, typically, two low-energy decomposition pathways are often competing:

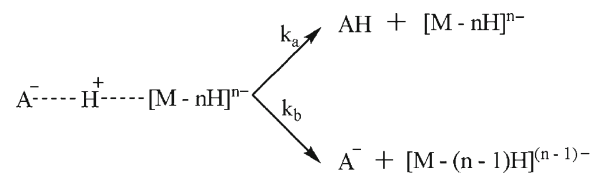

In the case of a singly charged proton-bound dimer (i.e., where $n=1$ ), the so-called "reverse activation energy barrier" is often considered to be close to zero. Even for a multiply charged peptide that is undergoing a neutral loss (Pathway 5a), the reverse activation energy barrier can still be considered to be negligible. By contrast, when a multiply charged peptide decomposes to form two charged product ions (Pathway 5b) electrostatic repulsion between the formed negatively charged peptide and the departing anion would create a significant reverse activation energy barrier, $\varepsilon_{\mathrm{o}}^{\mathrm{r}}$, which is equal to the Coulomb repulsion between the two charged productions. The presence of such a reverse activation barrier makes the activation energy required to pass through this exit channel appear greater than what would be anticipated by solely considering the intrinsic GB at the site in question. Hence, it is more correct to say that "matching of apparent GBs" rather than "matching of GBs" leads to increased stability of the proton-bound mixed dimer of anions.

\section{References}

1. Gurau, M.C., Lim, S.-M., Castellana, E.T., Albertorio, F., Kataoka, S., Cremer, P.S.: On the mechanism of the Hofmeister effect. J. Am. Chem. Soc. 126, 10522-10523 (2004)

2. Prell, J.S., O'Brien, J.T., Williams, E.R.: Structural and electric field effects of ions in aqueous nanodrops. J. Am. Chem. Soc. 133, 4810$4818(2011)$

3. Mirza, U.A., Chait, B.T.: Effects of anions on the positive ion electrospray ionization mass spectra of peptides and proteins. Anal. Chem. 66, 2898-2904 (1994)

4. Gregor, H.P., Belle, J., Marcus, R.A.: Studies on ion-exchange resins. XIII. Selectivity coefficients of quaternary base anion-exchange resins toward univalent anions. J. Am. Chem. Soc. 77, 2713-2719 (1955)

5. Cole, R.B., Zhu, J.: Chloride anion attachment in negative ion electrospray ionization mass spectrometry. Rapid Commun. Mass Spectrom. 13, 607-611 (1999)

6. Zhu, J., Cole, R.B.: Formation and decompositions of chloride adduct ions, $[\mathrm{M}+\mathrm{Cl}]^{-}$, in negative ion electrospray ionization mass spectrometry. J. Am. Soc. Mass Spectrom. 11, 932-941 (2000)

7. Zhu, J., Cole, R.B.: Ranking of gas-phase acidities and chloride affinities of monosaccharides and linkage specificity in collisioninduced decompositions of negative ion electrospray-generated chloride adducts of oligosaccharides. J. Am. Soc. Mass. Spectrom. 12, $1193-$ 1204 (2001)

8. Cai, Y., Cole, R.B.: Stabilization of anionic adducts in negative ion electrospray mass spectrometry. Anal. Chem. 74, 985-991 (2002)

9. Cai, Y., Concha, M.C., Murray, J.S., Cole, R.B.: Evaluation of the role of multiple hydrogen bonding in offering stability to negative ion adducts in electrospray mass spectrometry. J. Am. Soc. Mass Spectrom. 13, 1360-1369 (2002)

10. Cai, Y., Jiang, Y., Cole, R.B.: Anionic adducts of oligosaccharides by matrix-assisted laser desorption/ionization time-of-flight (MALDI-TOF) mass spectrometry. Anal. Chem. 75, 1638-1644 (2003)
11. Jiang, Y., Cole, R.B.: Oligosaccharide analysis using anion attachment in negative mode electrospray mass spectrometry. J. Am. Soc. Mass Spectrom. 16, 60-70 (2005)

12. Guan, B., Cole, R.B.: Differentiation of both linkage position and anomeric configuration in underivatized glucopyranosyl disaccharides by anion attachment with post-source decay in matrix-assisted laser desorption/ionization linear-field reflectron time-of-flight mass spectrometry. Rapid Commun. Mass Spectrom. 21, 3165-3168 (2007)

13. Guan, B., Cole, R.B.: MALDI linear-field reflectron TOF post-source decay analysis of underivatized oligosaccharides: Determination of glycosidic linkages and anomeric configurations using anion attachment. J. Am. Soc. Mass Spectrom. 19, 1119-1131 (2008)

14. Wang, W., Cole, R.B.: Enhanced collision-induced decomposition efficiency and unraveling of novel fragmentation pathways for anionic adducts of brevetoxins in negative ion electrospray mass spectrometry. Anal. Chem. 81, 8826-8838 (2009)

15. Mallard, W. G., Linstrom, P. J.: National Institute of Standards and Technology: Gaithersburg MD (http://webbook.nist.gov), accessed February, 2011.

16. Lias, G. L., Bartmess, J. E., Liebmann, J. F., Holmes, J. L., Levin, R. D., Mallard, W. G.: J. Phys. Chem. Ref. Data 17, 1(Suppl) (1988)

17. Breuker, K., Knochenmuss, R., Zenobi, R.: Gas-phase basicities of deprotonated matrix-assisted laser desorption/ionization matrix molecules. Int. J. Mass Spectrom. 184, 25-38 (1999)

18. Blondel, C., Cacciani, P., Delsart, C., Trainham, R.: High-resolution determination of the electron affinity of fluorine and bromine using crossed ion and laser beams. Phys. Rev. A 40, 3698-3701 (1989)

19. Liu, X., Cole, R. B.: Role of Anions in Determining Charge State Distributions of Peptides. Proceedings of the 59th ASMS Conference on Mass Spectrometry and Allied Topics; Denver, CO, June 7, 2011.

20. Gross, D.S., Rodriquezcruz, S.E., Bock, S., Williams, E.R.: Measurement of Coulomb energy and dielectric polarizability of gas-plate diprotonated diaminoalkanes. J. Phys. Chem. 99, 4034-4038 (1995)

21. Schnier, P.D., Gross, D.S., Williams, E.R.: On the maximum charge-state and proton-transfer reactivity of peptide and protein ions formed by electrospray-ionization. J. Am. Soc. Mass Spectrom. 6, 1086-1097 (1995)

22. Gross, D.S., Williams, E.R.: Experimental-measurement of Coulomb energy and intrinsic dielectric polarizability of a multiply protonated peptide ion using electrospray-ionization fourier-transform mass-spectrometry. J. Am. Chem. Soc. 117, 883-890 (1995)

23. Flick, T.G., Merenbloom, S.I., Williams, E.R.: A simple and robust method for determining the number of basic sites in peptides and proteins using electrospray ionization mass spectrometry. Anal. Chem. 83, 2210-2214 (2011)

24. Merenbloom, S. I., Flick, T. G., Williams, E. R.: Effects of Counterion on Sodium and Acid Adduction to Proteins: Implications for the ESIMS of Proteins and Complexes. Proceedings of the 59th ASMS Conference on Mass Spectrometry and Allied Topics. Denver, CO, June 8, 2011

25. Stephenson, J.L., McLuckey, S.A.: Counting basic sites in oligopeptides via gas-phase ion chemistry. Anal. Chem. 69, 281-285 (1997)

26. Stephenson, J.L., McLuckey, S.A.: Gaseous protein cations are amphoteric. J. Am. Chem. Soc. 119, 1688-1696 (1997)

27. Verkerk, U.H., Kebarle, P.: Ion-ion and ion-molecule reactions at the surface of proteins produced by nanospray. Information on the number of acidic residues and control of the number of ionized acidic and basic residues. J. Am. Soc. Mass Spectrom. 16, 1325 (2005)

28. Samalikova, M., Grandori, R.: Role of opposite charges in protein electrospray ionization mass spectrometry. J. Mass Spectrom. 38, 941947 (2003)

29. Li, Y., Cole, R.B.: Charge state distributions in electrospray and MALDI. In: Cole, R.B. (ed.) Electrospray and MALDI Mass Spectrometry Fundamentals, Instrumentation, Practicalities, and Biological Applications, pp. 491-534. Wiley Interscience Publications, John Wiley and Sons, New York, NY (2010)

30. Ravi, K.M., Prabhakar, S., Nagaveni, V., Vairamani, M.: Estimation of gas-phase acidities of a series of dicarboxylic acids by the kinetic method. Rapid Commun. Mass Spectrom. 19, 1053-1057 (2005)

31. Jones, C.M., Bernier, M., Carson, E., Colyer, K.E., Metz, R., Pawlow, A., Wischow, E.D., Webb, I., Andriole, E.J., Poutsma, J.C.: Gas-phase acidities of the 20 protein amino acids. Int. J. Mass Spectrom. 267, 54-62 (2007)

32. Kaltashov, I.A., Fenselau, C.: Thermochemistry of multiply charged melittin in the gas phase determined by the modified kinetic method. Rapid Commun. Mass Spectrom. 10, 857 (1996) 